\section{Prevalence of needle stick injuries and their underreporting among healthcare workers in the department of obstetrics and gynaecology}

\section{Abstract}

Introduction: Needle stick and sharp injuries (NSSIs) are hazardous and are frequently reported injuries among health care workers (HCW). These injuries expose them to infectious disease pathogens such as Hepatitis B, Hepatitis C and HIV that can be lethal. The physicians, nurses, medical students and other healthcare workers are highly susceptible to needle stick injuries. Standard precautions are available for all the workers and students' safety purposes. Every incident is compulsory to be reported but some are under-reported. This represents a missed opportunity for initiating post exposrure prophylaxis, early detection of seroconversion and implementation of prevention strategies.

Objectives: Obstetrics and Gynaecology Department is one of the department estimated as high risk of sharp injuries. The objective of the study is to identify the prevalence of needle stick and sharps injuries (NSSIs) and the rate of under-reporting to occupational health services. It also aims to explore the reasons for under-reporting and the knowledge, awareness and perception of risk of needle stick injuries in Obstetrics and Gynaecology Department of two teaching hospitals in Malaysia.

Methods: A cross-sectional study of 194 respondents involving all the healthcare workers and students (Specialists, Medical Officers, House officers, Nurses, Medical assistants, Medical students and
Kavitha Nagandla', Krishna Kumar², Amit Bhardwaj ${ }^{3}$, Devalagan a/l Muthalagan ${ }^{4}$, Chan Yhmin ${ }^{4}$, Lee Wei Lun ${ }^{4}$, Weng Wei Shi ${ }^{4}$, Nurul Izzati B. Abd Razak ${ }^{4}$

1 Senior Lecturer, Dept of Obstetrics and Gynaecology International medical University Jalan rasah Seermban

2 Consultant and Head of Department Department of Obstetrics and Gynaecology Hospital Tuanku Ja'afar Jalan Rasah 70300 Seremban, Negeri Sembilan, Malaysia

3 Specialist Orthopaedician Hospital Sultan Ismail Johor Bahru

4 Semester 7 students International medical University Jalan rasah Seermban, Malaysia, 70200

Contact information:

” kavitha.nagandla@gmail.com

Keywords

Underreporting needle stick and sharps injuries, healthcare workers, medical students, Knowledge, awareness and perception of risk of NSSIs, Obstetrics and Gynaecology Department. 


\section{Presented at $1^{\text {st }}$ International Online BioMedical Conference}

Vol. 8 No. 181 doi: $10.3823 / 1780$

nursing students) from Obstertrics and Gynaecology wards in two teaching hospitals who are willing to participate were included. A structured questionnaire was used as the survey instrument. By using statistical analysis, we compared the data of sociodemographics of health workers, injury information, knowledge on risk of needle stick injury and risk perception on needle stick injury.

Results: Out of 194 respondents, a total of 19(9.8\%) respondents sustained needle stick injury. The prevalence was highest among medical student, $42.1 \%(n=8)$. Among the 19 cases, 36.8\% did not report the incident due to perceived low risk of Hepatitis B/Human Immuno deficiency virus infection (42.9\%), and that it was not important to report the incident (28.6\%).

Conclusion: There is a fair understanding of Universal Work Precaution among the HWCs in the Department of Obstetrics and Gynaecology in both the hospitals. However, there still exist a large gap between their knowledge, attitude and practice of the universal work precaution. As noted in the study, the highest prevalence of needle stick injury and its' under-reporting is among medical students. Therefore, exposure prevention among the students must be an institutional concern, although every student must be aware of their responsibility for this prevention. Completion of three doses of Hepatitis B must be reiterated and HWCS must also be aware of their antibody status.

\section{Introduction}

Needle stick injuries (NSIs) are common occurrences in hospitals and health care workers (HWCs), particularly physicians and nurses are at highest risks but auxillary staff and medical students can also experience NSIs. This exposes them to risk of various blood borne pathogens such as Hepatits B, Hepatits $C$ and Human Immunodeficiency virus." According to WHO Health report 2002, out of the 35 million health-care workers, million experience percutaneous exposure to infectious diseases each year. It is further estimates that $37.6 \%$ of Hepatitis B, 39\% of Hepatitis C and $4.4 \%$ of HIVIAIDS in Health-Care
Workers around the world are due to needle stick injuries $^{2}$. Further more, the annual global estimated proportion of health care workers exposed to these infections were $0.5 \%$ for HIV, $2.6 \%$ for HBV and 5.95\% for HCV. 2,3

Besides that, the long term outcome of HCWs who sustained needle stick injury includes substantial psychiatric morbidity such as depression, posttraumatic stress disorder and adjustment disorder. The attendant consequences to these effects include missed work days which directly affect the health care services and resources ${ }^{4}$. It is obvious that NSIs are the commonest occupational hazard and it can lead to debilitating complication such as 


\section{Presented at $1^{\text {st }}$ International Online BioMedical Conference}

Vol. 8 No. 181 doi: $10.3823 / 1780$ infection and psychiatric morbidity.

The National Institute for Occupational Safety and Health, United States defines needle stick injuries as injuries caused by needles such as hypodermic needle, blood collection needles, intravenous stylets, and needles used to connect parts of intravenous delivery systems ${ }^{5}$. The Ministry of Health Malaysia defines needlestick injury as injury caused by suture or hollow-bore needles ${ }^{6}$.The Department of Occupational Safety and Health of Malaysia have also published a code of practice on prevention and management of HIV and AIDS for the purpose of workplace references ${ }^{7}$.

Despite the standard of procedure (SOP) that is available on sustaining needle stick injuries, a Malaysian study reported that about $59 \%$ of cases of needle stick injury did not report their injuries and cases of needle stick injuries attained lower scores on practice of universal precautions compared to non-cases ${ }^{8}$.

\section{Objectives}

To determine (1) the prevalence of underreporting of needle stick injury (NSIs), (2) the reasons for under-reporting and (3) the knowledge, awareness and perception of universal precaution of needle stick injury among healthcare workers (HCWs) including medical and nursing students in Obstetrics and Gynaecology Department in two hospitals in the state of Seremban, Malaysia.

\section{Methodology}

This is a cross-sectional study done in Obstetrics and Gynecology Department of two teaching hospitals in Malaysia. This study is approved by the ethical commitee and the study period is from July 2014 to January 2015. Sample size was calculated according to the formula by Daniel, (1999) cited by
Naing et al. (2006) as follows: $-n=\left[Z^{2} P(1-P)\right] / d^{2}$ whereby; $n=$ sample size, $Z=Z$ statistic for a level of confidence; (1.96 at confidence level of 95\%), $P$ $=0.9$ and $d=0.05$ as precision is $5 \%$.

All the healthcare providers including all Doctors (Consultants, Specialists, Medical Officers, House officers), Nurses, Medical assistants, Medical students and nursing students of the Obstetrics and Gynecology wards who are willing to participate are included in this study. Health care workers who are not willing to participate are excluded from this study.

A structured validated questionnaire were used as the survey instrument. The questionnaire was developed from WHO Aide Memoire of standard precuations in health care. There are 4 sections in the questionnaires. The sections are the sociodemographic character of healthcare workers, questions regarding the needle sticks injury, questions on knowledge of risk of needle stick injury and the risk perception on needle stick injury.

To conduct this study in the Obstetrics and Gynecology Department of Hospital Tuanku Jaafar Seremban and Hospital Port Dickson, approval from Director of the hospital and Head of department from respective hospital were taken.

An informed written consent was taken from every participant. The information obtained during the data collection will be strictly kept confidential. In order to maintain anonymity, a random code number was issued to each participant of this study while responding to the questionnaire. All the collected data were tabulated and analyzed by using the statistical package for social science, SPSS, version 16.0. The data were screened for accuracy and incomplete data were excluded from analysis. To assess perception, five points Likert scale was used for scoring, 5. Strongly agree, 4. Agree 3. Not Sure 2. Disagree and 1. Strongly Disagree. The Chi Square test is used and the association between these variables is explored through univariate analysis and multivariable logistic regression. 


\section{Results}

\section{Sociodemography}

Of 194 respondents who took part in our research, $63.9 \%(n=124)$ of them were less than 25 years and $36.1 \%(n=70)$ of them were above 25 years old. Regarding the ethinicity, majority of respondents were Malay $49.5 \%(n=96)$. This is followed by Chinese $31.4 \%(n=61)$, Indian $15.5 \%(n=30)$ and others $3.6 \%(n=7)$. Among the respondents, $79.4 \%(n=40)$ of them were female and $20.6 \%(n=154)$ of them were male.

Majority of the respondents were medical students who comprised $42.3 \%(n=82)$ of all. It was followed by staff nurses, 30.9\%( $n=60)$, nursing students $13.4 \%(n=26)$ house officers $7.2 \%(n=14)$ and $4.1 \%(n=9)$ are medical officers. Others such as community health workers comprised $1.5 \%(n=3)$ of total. Only $0.5 \%(n=1)$ of total were specialist doctors. Among the respondents, 95.9\% $(n=186)$ completed their vaccination against Hepatitis $B$ and $4.1 \%(n=8)$ did not. Among those who have yet to complete the Hepatitis B vaccination, 2 were house officers, 2 were staff nurses, 3 were medical students and 1 was nursing student (Table 1).

\section{Needle stick injury information and reasons for under-reporting}

There were a total of $19(9.8 \%)$ cases of needle stick injury reported in this study. The prevalence of needle stick injury was highest among medical student, $42.1 \%(n=8)$, followed by medical officer $26.3 \%(n=5)$, staff nurse $15.8 \%(n=3)$, house officer

Table 1. Sociodemographic data

\begin{tabular}{|c|c|c|c|}
\hline \multicolumn{2}{|c|}{ Sociodemographic data } & \multirow{2}{*}{$\begin{array}{l}\text { Frequency } \\
\qquad \begin{array}{c}\text { (n) } \\
124\end{array}\end{array}$} & \multirow{2}{*}{$\begin{array}{c}\text { Valid Percent (\%) } \\
63.9\end{array}$} \\
\hline & $<25$ Years & & \\
\hline Age & $>25$ Years & 70 & 36.1 \\
\hline & Male & 40 & 20.6 \\
\hline sex & Female & 154 & 79.4 \\
\hline \multirow{4}{*}{ Ethnicity } & Malay & 96 & 49.5 \\
\hline & Chinese & 61 & 31.4 \\
\hline & Indian & 30 & 15.5 \\
\hline & Others & 7 & 3.6 \\
\hline \multirow{7}{*}{ Medical Profession (Category) } & Specialist & 1 & .5 \\
\hline & Medical Officer & 8 & 4.1 \\
\hline & House officer & 14 & 7.2 \\
\hline & Staff nurse & 60 & 30.9 \\
\hline & Medical student & 82 & 42.3 \\
\hline & Nursing student & 26 & 13.4 \\
\hline & Others & 3 & 1.5 \\
\hline \multirow{2}{*}{ Total years of experience in the profession (years) } & $<5$ years & 47 & 50.5 \\
\hline & $>5$ years & 46 & 49.5 \\
\hline \multirow{2}{*}{$\begin{array}{l}\text { Are three doses of hepatitis B vaccination } \\
\text { completed? }\end{array}$} & Yes & 186 & 95.9 \\
\hline & No & 8 & 4.1 \\
\hline \multirow{2}{*}{$\begin{array}{l}\text { Are you aware that universal work precaution } \\
\text { prevent Needle stick injury }\end{array}$} & Yes & 182 & 93.8 \\
\hline & No & 12 & 6.2 \\
\hline
\end{tabular}


Table 2. Sources of information about universal precaution by respondents

\begin{tabular}{|l|c|c|}
\hline $\begin{array}{c}\text { Sources of information about } \\
\text { universal precaution by } \\
\text { respondents }\end{array}$ & $\begin{array}{c}\text { Frequency } \\
\text { (n) }\end{array}$ & $\begin{array}{c}\text { Valid } \\
\text { Percent } \\
\text { (\%) }\end{array}$ \\
\hline Medical or Nursing School & 112 & 57.7 \\
\hline Hospital & 122 & 62.9 \\
\hline Brochure & 30 & 15.5 \\
\hline Mass media & 44 & 22.7 \\
\hline
\end{tabular}

$10.5 \%(n=2)$ and specialist $5.3 \%(n=1)$. Both nursing student and others have not reported any case of needle stick injury.

The most common instrument that caused the injury was hollow bore needle in $52.6 \%(n=10)$. It was followed by solid needle, $36.8 \%(n=7)$ and then others, $10.5 \%(n=2)$. Majority of the incidents happened during intravenous canulation (36.8\%, 7 out of 19 cases). In this study, $78.9 \%(n=15)$ reported the injury was self-inflicted, $15.8 \%(n=3)$ was caused by others and $5.3 \%(n=1)$ reported that the injuries were caused by both self-inflicted and others. For the perceived cause of injury, $52.6 \%(n=10)$ stated that the injury was caused by them being in rush and $10.5 \%(n=2)$ reported due to fatigueability. Of 19 cases of injury, $36.8 \%(n=7)$ reported they had not taken post exposure action after the injury.
Medical students have the highest percentage of not taking post exposure action, comprising $71.4 \%$ $(n=5)$. Both house officers and specialist have the same percentage of not taking post exposure action, $14.3 \%(n=1)$. For those who had not reported, reasons $42.9 \%$ stated were the low risk perception of HIV/ Hep B or C of the patient and $28.6 \%$, thought it was not important to report. Analysis of the data shows no association between the knowledge of universal precaution for needle stick injury and the presence of post exposure action (Tables 2, 3 and 4).

\section{Knowledge of Universal work precautions and its risk perception}

In this study, $93.8 \%(n=182)$ of the respondents had adequate knowledge on universal precaution. Only 2 house officers, 4 medical students, 6 nursing students reported that they have no prior knowledge on universal precaution. About $62.9 \%(n=122)$ of respondents reported the knowledge source of universal precaution is from hospital orientation trainings and teaching in wards by senior professionals. $57.7 \%(n=112)$ of total respondents stated that they learned it from their respective medical or nursing school. $22.7 \%(n=44)$ reported mass media and $15.5 \%(n=30)$ mentioned brochure as source of knowledge as the source.

Regarding knowledge of risk perception of needle stick injury, it was found that $83.0 \%(n=161)$ of res-

Table 3. Hepatitis B vaccination by the respondents

\begin{tabular}{|c|c|c|c|c|}
\hline \multirow{3}{*}{ Medical Profession } & \multicolumn{4}{|c|}{ Have you completed your three doses of Hepatitis B vaccination? } \\
\hline & \multicolumn{2}{|c|}{ Yes } & \multicolumn{2}{|c|}{ No } \\
\hline & n & $\%(\%)$ & n & $\%(\%)$ \\
\hline Specialist & 1 & 0.5 & 0 & 0.0 \\
\hline Medical Officer & 8 & 4.3 & 0 & 0.0 \\
\hline House Officer & 12 & 6.5 & 2 & 25.0 \\
\hline Staff Nurse & 58 & 31.2 & 2 & 25.0 \\
\hline Medical Student & 79 & 42.5 & 3 & 37.5 \\
\hline Nursing Student & 25 & 13.4 & 1 & 12.5 \\
\hline Others & 3 & 1.6 & 0 & 0.0 \\
\hline
\end{tabular}




\section{INTERNATIONAL ARCHIVES OF MEDICINE \\ Section: International Online Medical Conference \\ ISSN: 1755-7682}

\section{Presented at $1^{\text {st }}$ International Online BioMedical Conference}

Vol. 8 No. 181 doi: $10.3823 / 1780$

Table 4. Knowledge on universal precaution for needle stick injury by medcial profession category

\begin{tabular}{|c|c|c|c|c|}
\hline \multirow{3}{*}{ Medical Profession } & \multicolumn{4}{|c|}{ Do you know about universal precaution for needle stick injury? } \\
\hline & \multicolumn{2}{|c|}{ Yes } & \multicolumn{2}{|c|}{ No } \\
\hline & n & $\%(\%)$ & n & $\%(\%)$ \\
\hline Specialist & 1 & 0.5 & 0 & 0 \\
\hline Medical Officer & 8 & 4.4 & 0 & 0 \\
\hline House Officer & 12 & 6.6 & 2 & 16.7 \\
\hline Staff Nurse & 60 & 33.0 & 0 & 0.0 \\
\hline Medical Student & 78 & 42.9 & 4 & 33.3 \\
\hline Nursing Student & 21 & 11.5 & 5 & 41.7 \\
\hline Others & 2 & 1.1 & 1 & 8.3 \\
\hline
\end{tabular}

pondents had good level of knowledge. In $17 \%(n=33)$ who had insufficient knowledge, medical students formed the highest percentage $33.3 \%(n=11)$, followed by staff nurses $30.1 \%(n=10)$, nursing students $18.2 \%(n=6)$, house officers $9.1 \%(n=3)$, others $6.1 \%(n=2)$ and medical officer $3.0 \%(n=1)$. There is no association between practice of post exposure action after the injury with knowledge on universal precautions or risk perception of needle stick injury. (p>0.05) (Tables 5, 6 and 7).

\section{Knowledge on risk of needle stick injury}

In this study, $71.6 \%(n=139)$ of respondents were found to have a high perception level towards needle stick injury. There is an association between the prior knowledge of universal precaution for needle stick injury with perception level of respondents. Those who have prior knowledge of universal precaution for NSI are 3.9 times more likely to have a higher perception level (Tables 8 and 9).

Table 5. Mechanism of needle stick injury among the different professional category

\begin{tabular}{|c|c|c|c|c|c|c|c|}
\hline & \multirow[b]{2}{*}{ IM Injection } & \multicolumn{6}{|c|}{ Mechanism of injury } \\
\hline & & $\begin{array}{c}\text { IV } \\
\text { cannulation }\end{array}$ & $\begin{array}{l}\text { Withdraw } \\
\text { blood }\end{array}$ & $\begin{array}{l}\text { Assist in } \\
\text { theatre }\end{array}$ & $\begin{array}{c}\text { Recapping } \\
\text { needle }\end{array}$ & Others & \\
\hline \multirow{5}{*}{ 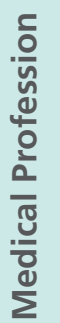 } & Specialist & & & & & & 1 \\
\hline & Medical Officer & & & 3 & 3 & & 1 \\
\hline & House Officer & & 1 & 1 & & & \\
\hline & Staff Nurse & 1 & & & & 1 & 1 \\
\hline & Medical Student & & 1 & 3 & & 1 & 4 \\
\hline
\end{tabular}




\section{Presented at $1^{\text {st }}$ International Online BioMedical Conference}

Table 6. Relationship between Hep B vaccination status and prior knowledge about universal precaution with prevalence of needle stick injury

\begin{tabular}{|c|c|c|c|c|c|c|c|c|c|}
\hline & \multicolumn{5}{|c|}{$\begin{array}{c}\text { Did you have any needle stick injury } \\
\text { before? }\end{array}$} & \multirow{3}{*}{$P$ value } & \multirow{3}{*}{$\mathrm{X} 2$} & \multirow{3}{*}{$\begin{array}{l}\text { Odd } \\
\text { ratio }\end{array}$} & \multirow{3}{*}{$\begin{array}{l}\text { Confidence } \\
\text { interval }\end{array}$} \\
\hline & \multicolumn{2}{|c|}{ Yes } & \multicolumn{2}{|c|}{ No } & & & & & \\
\hline & $n$ & $\%(\%)$ & n & $\%(\%)$ & & & & & \\
\hline \multirow{2}{*}{ 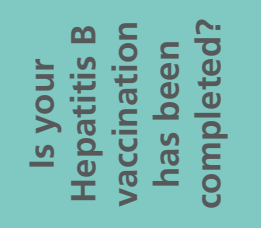 } & Yes & 19 & 10.2 & 167 & 89.8 & \multirow{2}{*}{0.34} & \multirow{2}{*}{0.91} & \multirow{2}{*}{0.9} & \multirow{2}{*}{$0.86-0.94$} \\
\hline & No & 0 & 0 & 8 & 100 & & & & \\
\hline \multirow{2}{*}{ 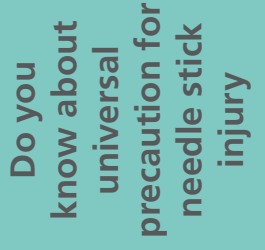 } & Yes & 18 & 9.9 & 164 & 90.1 & \multirow{2}{*}{0.86} & \multirow{2}{*}{0.03} & \multirow{2}{*}{1.21} & \multirow{2}{*}{$0.15-9.9$} \\
\hline & No & 1 & 8.3 & 11 & 91.7 & & & & \\
\hline
\end{tabular}

Table 7. Relationship between Medical Profession and Underreporting of the injury

\begin{tabular}{|c|c|c|c|c|}
\hline \multirow{3}{*}{ Medical Profession } & \multicolumn{4}{|c|}{ Have you taken post exposure action after injury? } \\
\hline & \multicolumn{2}{|c|}{ Yes } & \multicolumn{2}{|c|}{ No } \\
\hline & $\mathbf{n}$ & $\%(\%)$ & $\mathbf{n}$ & $\%(\%)$ \\
\hline Specialist & 0 & 0.0 & 1 & 14.3 \\
\hline Medical Officer & 5 & 41.7 & 0 & 0.0 \\
\hline House Officer & 1 & 8.3 & 1 & 14.3 \\
\hline Staff Nurse & 3 & 25.0 & 0 & 0.0 \\
\hline Medical Student & 3 & 25.0 & 5 & 71.4 \\
\hline Nursing Student & 0 & 0.0 & 0 & 0.0 \\
\hline Others & 0 & 0.0 & 0 & 0.0 \\
\hline
\end{tabular}




\section{Presented at $1^{\text {st }}$ International Online BioMedical Conference}

\section{Discussion}

The study was conducted in two tertiary level hospitals which covered various levels of professional hierarchy of a hospital to determine the prevalence of needle stick injuries (NSIs), reasons of underreporting, their knowledge and perception on NSIs, and practice of universal work precaution among health care workers (HWCs). The study included specialist $(0.5 \%)$, medical officers $(4.1 \%)$, house officers $(7.2 \%)$, staff nurse $(30.9 \%)$, medical student $(42.3 \%)$, nursing students $(13.4 \%)$ and others $(1.5 \%)$. It is reported globally that there are almost 3 million people are exposed to blood bor-

Table 8. Relationship between prior knowledge of universal precaution with post exposure action

\begin{tabular}{|c|c|c|c|c|c|c|c|c|c|}
\hline & \multicolumn{5}{|c|}{ Have you taken post exposure action after injury? } & \multirow{3}{*}{$P$ value } & \multirow{3}{*}{$\times 2$} & \multirow{3}{*}{$\begin{array}{l}\text { Odd } \\
\text { ratio }\end{array}$} & \multirow{3}{*}{$\begin{array}{c}\text { Confidence } \\
\text { interval }\end{array}$} \\
\hline & \multicolumn{2}{|c|}{ Yes } & \multicolumn{2}{|c|}{ No } & & & & & \\
\hline & n & $\%(\%)$ & n & $\%(\%)$ & & & & & \\
\hline 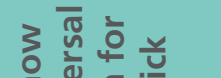 & Yes & 12 & 66.7 & 6 & 33.3 & \multirow{2}{*}{0.18} & \multirow{2}{*}{1.81} & & \\
\hline 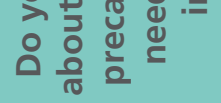 & No & 0 & 0 & 1 & 100 & & & & \\
\hline
\end{tabular}

Table 9. Respondents information about needle stick injury

\begin{tabular}{|c|c|c|c|}
\hline & & Frequency & Valid Percent (\%) \\
\hline \multirow{2}{*}{$\begin{array}{l}\text { Did you have any needle stick injury } \\
\text { before? }\end{array}$} & Yes & 19 & 9.8 \\
\hline & No & 175 & 90.2 \\
\hline \multirow{3}{*}{ If yes, total number of injury } & 1 & 11 & 57.9 \\
\hline & 2 & 5 & 26.3 \\
\hline & 3 & 3 & 15.8 \\
\hline \multirow{2}{*}{ In 2011? } & Yes & 2 & 10.5 \\
\hline & No & 16 & 89.5 \\
\hline \multirow{2}{*}{ In 2012? } & Yes & 3 & 15.8 \\
\hline & No & 16 & 84.2 \\
\hline \multirow{2}{*}{ In 2013? } & Yes & 9 & 47.4 \\
\hline & No & 10 & 52.6 \\
\hline \multirow{2}{*}{ In 2014? } & Yes & 7 & 36.8 \\
\hline & No & 12 & 63.2 \\
\hline \multirow{3}{*}{$\begin{array}{l}\text { Type of instruments that caused the } \\
\text { injury }\end{array}$} & Solid needle & 7 & 36.8 \\
\hline & Hollow bore needle & 10 & 52.6 \\
\hline & Others & 2 & 10.5 \\
\hline
\end{tabular}




\section{Presented at $1^{\text {st }}$ International Online BioMedical Conference}

\begin{tabular}{|c|c|c|c|c|}
\hline & & & \\
\hline & & & Frequency & Valid Percent (\%) \\
\hline \multirow{12}{*}{ 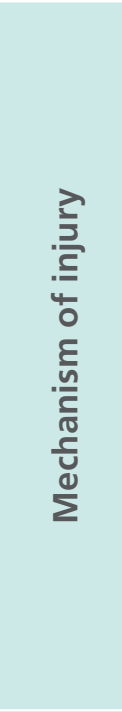 } & \multirow{2}{*}{ Injection } & Yes & 1 & 5.3 \\
\hline & & No & 18 & 94.7 \\
\hline & \multirow{2}{*}{ Intravenous cannulation } & Yes & 2 & 10.5 \\
\hline & & No & 17 & 89.5 \\
\hline & \multirow{2}{*}{ During blood withdrawing } & Yes & 7 & 36.8 \\
\hline & & No & 12 & 63.2 \\
\hline & \multirow{2}{*}{ Assist in theatre } & Yes & 3 & 15.8 \\
\hline & & No & 16 & 84.2 \\
\hline & \multirow{2}{*}{ Recapping needle } & Yes & 2 & 10.5 \\
\hline & & No & 17 & 89.5 \\
\hline & \multirow{2}{*}{ Other } & Yes & 7 & 36.8 \\
\hline & & No & 12 & 63.2 \\
\hline \multirow{3}{*}{\multicolumn{2}{|c|}{ Injury was caused by }} & Self-inflicted & 15 & 78.9 \\
\hline & & Someone else & 3 & 15.8 \\
\hline & & Both & 1 & 5.3 \\
\hline \multirow{2}{*}{\multicolumn{2}{|c|}{$\begin{array}{l}\text { Were u wearing gloves at the time of } \\
\text { injury? }\end{array}$}} & Yes & 12 & 63.2 \\
\hline & & No & 7 & 36.8 \\
\hline \multirow{4}{*}{\multicolumn{2}{|c|}{ What is the cause of injury? }} & Lack of time & 10 & 52.6 \\
\hline & & Improper assiatance & 0 & .0 \\
\hline & & Fatiguability & 2 & 10.5 \\
\hline & & No previous expereince & 3 & 15.8 \\
\hline \multirow{2}{*}{\multicolumn{2}{|c|}{$\begin{array}{l}\text { Did post exposure action taken } \\
\text { immediately after the injury? }\end{array}$}} & Yes & 12 & 63.2 \\
\hline & & No & 7 & 36.8 \\
\hline \multirow{12}{*}{ 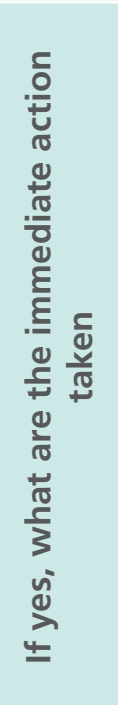 } & \multirow{2}{*}{$\begin{array}{c}\text { Imemdiate cleaning the } \\
\text { wound }\end{array}$} & Yes & 12 & 100.0 \\
\hline & & No & 0 & .0 \\
\hline & \multirow{2}{*}{ Stop the bleeding } & Yes & 7 & 8.4 \\
\hline & & No & 5 & 41.7 \\
\hline & \multirow{2}{*}{$\begin{array}{l}\text { Test blood for Inefctions } \\
\text { such as Hepatitis A, B and C }\end{array}$} & Yes & 7 & 58.3 \\
\hline & & No & 5 & 41.7 \\
\hline & \multirow{2}{*}{$\begin{array}{l}\text { Take Hepatitis B } \\
\text { immunization }\end{array}$} & Yes & 3 & 25.0 \\
\hline & & No & 9 & 75.0 \\
\hline & \multirow{2}{*}{$\begin{array}{l}\text { Take post exposrure } \\
\text { prophylaxis regime }\end{array}$} & Yes & 3 & 25.0 \\
\hline & & No & 9 & 75.0 \\
\hline & \multirow{2}{*}{ Others } & Yes & 1 & 8.3 \\
\hline & & No & 11 & 91.7 \\
\hline
\end{tabular}




\begin{tabular}{|c|c|c|c|c|}
\hline & & & \\
\hline & & & Frequency & Valid Percent (\%) \\
\hline \multirow{12}{*}{ 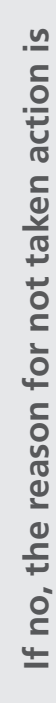 } & \multirow{2}{*}{$\begin{array}{c}\text { There is no enough time to } \\
\text { report }\end{array}$} & Yes & 0 & 0 \\
\hline & & No & 7 & 100.0 \\
\hline & \multirow{2}{*}{$\begin{array}{l}\text { I have no knowledge of the } \\
\text { reporting system }\end{array}$} & Yes & 0 & 0 \\
\hline & & No & 7 & 100.0 \\
\hline & \multirow{2}{*}{$\begin{array}{l}\text { I am worried about } \\
\text { confidentiality }\end{array}$} & Yes & 0 & 0 \\
\hline & & No & 7 & 100.0 \\
\hline & \multirow{2}{*}{$\begin{array}{l}\text { The patient is at low risk of } \\
\text { HIV and/or Hepatitis B or C }\end{array}$} & Yes & 3 & 42.9 \\
\hline & & No & 4 & 57.1 \\
\hline & \multirow{2}{*}{ It is not important to report } & Yes & 2 & 28.6 \\
\hline & & No & 5 & 9.0 \\
\hline & \multirow{2}{*}{ Others } & Yes & 2 & 28.6 \\
\hline & & No & 5 & 71.4 \\
\hline
\end{tabular}

Graph 1. Relationship between medical profession and prevalence of needle stick injury

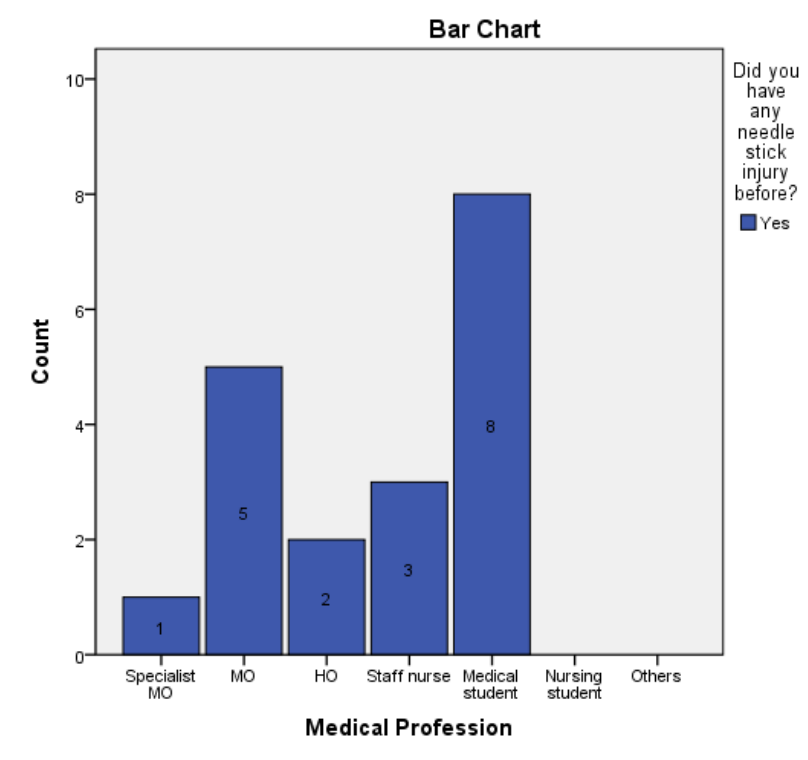

ne viruses annually globally through percutaneous injuries, non-intact skin or mucosa ${ }^{[10]}$.

The prevalence of needle stick injury in our study is the highest among the medical students (42.1\%), followed by medical officers $(26.3 \%)$, staff nurses
(15.8\%), house officers (10.5\%), specialist (5.3\%) and no cases was reported among the nursing students (Graph 1). A Siberian study reported the prevalence of needle stick injury among medical student as $9.8 \%{ }^{[11]}$ and in the study conducted by Fernanda and Larissa et al in Brazil it was reported to be $20.9 \%{ }^{[12]}$ A recent study showed prevalence of needle stick injury is $19.9 \%$ in medical students and majority of it occurred at medical ward.[13] Lack of experience, increased workload and tiredness were the main reasons for the occurrences of needle stick injuries which are similarly observed in other studies involving medical students where it was noted that it is likely due to an increase in the number of procedures to be performed by the students as they progress through their semesters, inexperience in performing the medical procedures, increased workload and fatigue thus leading to needle stick injuries [14]. The medical doctors (MOs, and Hos) usually sustained needle stick injury either when they are assisting in the theatre or withdrawing blood. There are studies demonstrating high incidence of needle stick injuries among nurses as administration of percutaneous injections and drawing of blood are mainly done by them however so, they 
reported third in our study. ${ }^{[15-18]}$ The reason for this could be that our sample size is mainly consisted of medical student. S. Pattinaik and D. Pattanaik et al reported $66.7 \%$ prevalence rate among the nurses in East India ${ }^{[19]}$ and similar reasons are noted in several studies. The practice of needle recapping has long forbidden according to the WHO guidelines since 1987 but it is still widely practiced. This clearly shows that there is a redundancy between the knowledge and practice of the Universal Work Precaution.

According to a study on incidence of needle stick injury and factors associated with this problem among medical students in Malaysia done in 2002, out of 417 medical students who handled hollow-bore needles in their clinical postings, 59 admitted experiencing at least one needle stick injury, an incidence of $14.1 \%$. $96.4 \%$ of students agreed that among all postings the needles they handled most were in Obstetrics \& Gynaecology. Meanwhile, the most common procedures involving handling needles were venepuncture $(99.5 \%)$, setting up drips (95\%) and giving parenteral injections (71.0\%). ${ }^{8}$ This study showed that all final year students involved in the study were exposed to the risk of exposure to blood-borne diseases such as HIV and AIDS through needle stick injury since all of them handled hollow-bore needles to perform procedures on patients in their routine clinical activities. The findings of the study did not reveal any significant difference between the level of knowledge of blood-borne pathogens and Universal Precautions among cases and non-cases even though the scores for the knowledge of both for cases were lower than that of non-cases. It is believed that this is because formal training had been carried out and only a small number of cases had not acquired sufficient knowledge regarding this matter. One study reported incidence of needle stick injury is $19.9 \%$ among medical students with the maximum reported to have occurred in the medical ward. The cause of injury is related to lack of experience during recap- ping of the needle.

In the United States, needle stick injuries have decreased exponentially over the years from an estimated one million exposure per year in 1996 to 385,000 per year in 2010 . This decline was a result from the protection afforded by the Occupational Safety and Health Administration's (OSHA) Blood borne Pathogens Standard. It has been attributed that the decrease was a result of the success in the elimination of needle recapping, and the use of safer needle devices and personal protective gears as well as sharps collection boxes and universal precautions. $^{9}$

In a cross sectional study done among $345 \mathrm{HCWs}$ in Serdang Hospital, it has been reported that the prevalence of the needle stick injury was $23.5 \%$. Staff nurses had the highest prevalence reporting with an incident of $27.9 \%$. It has been reported that the hypodermic needles were among the highest with $58 \%$ and $27.2 \%$ cases were recapping. More than $95 \%$ of the majority reported that they are aware of the universal precaution and that needle stick injury has to be reported and has the knowledge on HIVIAIDS transmission through bodily fluid and blood. However only 30.9\% have reported the incident of needle stick injury and this indicates that, there is a gap between the knowledge and practice among the HCWs. ${ }^{10}$ Although the knowledge on Universal Precaution is good, the prevalence of NSIs is still high and there are loop holes between the knowledge and practice of the reporting thus it can be safely concluded that NSIs continue to pose a serious occupational problem.

According to the policy of the NHS in the UK, it is compulsory when staff sustain a needle-stick injury to report the incident. However, evidence from the US suggests that more than half of all sharpsrelated injuries are not reported. Poor reporting of sharps-related injuries reveals a failure to appreciate the potential consequences of such injuries. Rates of detection are also low, for example, only $11 \%$ of glove perforations were detected by the physician in 
a study investigating the use of blunt needles during obstetrical laceration repair surgeries. ${ }^{11}$

The prevalence of under-reporting of needle stick injury in our study is $38.6 \%$ as compared to $58.6 \%$ as reported by Voide $C$ et al and Darling Ke et al ${ }^{[13]}$, in Malaysia, it is up to $59 \%$ in a study conducted by Lee and Hashim et al in 2005 while a retrospective study done in the UK states that the degree of underreporting may be as much as 10-fold. ${ }^{[14]}$

The majority of the study group in our study were under 25 years of age (63.9\%)) and based on our results, the older age group is 2.7 times (1/0.37) more likely to get needle stick injury because of they have a longer career span as compared to those of a younger age group. However, it is found that the risk is expected to be higher in relatively younger age group as they are least experienced and they tend to ignore the universal work precaution ${ }^{[12]}$.

It was reported in our study that 95.9\% has completed their Hepatitis B vaccination while $4.1 \%$ did not and the latter pose a significant hazard towards the HWCs as they are at a risk of infection because of the inadequacy in antibody response. It is estimated that $37.6 \%$ of Hepatitis B, $39 \%$ of Hepatitis C and $4.4 \%$ of HIVIAIDS globally are a result of needle stick injury amongst the HWCs ${ }^{[1]}$. 93.8\% of our respondent noted that they are aware of the universal work precaution while $6.2 \%$ were not aware of the guidelines. Out of $93.8 \%$ that are aware of the universal work precaution, only $85.7 \%$ exhibited good knowledge and the medical students noted to have a slightly better knowledge than the HWCs. This is probably due to teaching materials that are readily available in the university and having practical sessions in the clinical session unit facilitated by well-trained tutors. However so, it is still worrisome as most claimed to know the universal work precaution but there is a knowledge gap on the precaution guidelines and it is likely due to the lack of emphasis in the implementation of the universal work precaution. It is noted in our study that the majority lacks knowledge on the post exposure pro- phylaxis and this has to be taken into consideration and adequate knowledge has to be instilled among the HCWs and this has to be reemphasized that not the knowledge alone is sufficient but the implementation of the acquired knowledge that will prevent the health care workers from the risk of NSIs and of which with the subsequent reporting that will benefit them by timely intervention.

There was a total of 19 cases reported positive for needle stick injuries in our study of which $36.8 \%$ did not take any post exposure prophylaxis and based on our data, these respondents has had their Hepatitis B vaccination done and they claimed to know the universal work precaution but they show a moderate knowledge on the guidelines. However so, they did not report and the reasons for underreporting are that they thought the patient had low risk of Hepatitis B/HIV (42.9\%), 28.6\% reported that it was not important to report the incident and others (28.6\%). In our hospital, a telephone hotline managed by the occupational health service is in place, and all staff are encouraged to report every NSSI involving blood and body fluids. In spite of this, a proportion of NSSIs goes unreported.

Medical students have the highest percentage of underreporting, comprising $71.4 \%(n=5)$. Both house officers and specialist have the same percentage of under-reporting of the needle tsick injury $14.3 \%$ $(n=1)$ (Tables 10 and 11). In Arman and Monireh et al, it has been shown that the surgeons or nurses are only interested in reporting the incidences if the contaminant was known to be infected with blood borne pathogens ${ }^{[15]}$. In the same study it was also noted that only $22 \%$ reported every case of needle stick injury and in a study conducted in Japan, Smith et al 2009 , it was reported that $43.3 \%$ of nurses has never reported any needle stick injuries sustained by them over the past 12 months because they thought that the issue was not important ${ }^{[16,20,21]}$. Other perceived cause of under-reporting included them being in a rush or too busy and fatigue. Interestingly our study 


\section{Table 10: Respondents knowledge on universal work precautions}

\begin{tabular}{|c|c|c|c|c|}
\hline & & & Frequency & Valid Percent (\%) \\
\hline \multirow{3}{*}{ 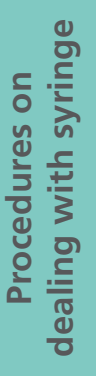 } & $\begin{array}{c}\text { The used syringes disposed into } \\
\text { regular trash can cause needle } \\
\text { stick injury }\end{array}$ & Know & 178 & 91.8 \\
\hline & $\begin{array}{c}\text { It is necessary to recap the used } \\
\text { syringes before you discarding } \\
\text { them away }\end{array}$ & Know & 184 & 94.8 \\
\hline & $\begin{array}{l}\text { It is necessary to sterilize sharp } \\
\text { instruments before reuse }\end{array}$ & Know & 92 & 47.4 \\
\hline \multirow{5}{*}{ 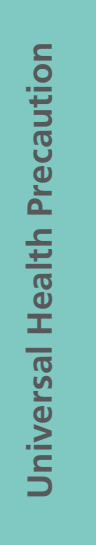 } & $\begin{array}{l}\text { Hand washing after any direct } \\
\text { contact with patients }\end{array}$ & Know & 166 & 85.6 \\
\hline & Needle recapping & Know & 170 & 87.6 \\
\hline & $\begin{array}{l}\text { Safe collection and disposal } \\
\text { sharps }\end{array}$ & Know & 188 & 96.9 \\
\hline & $\begin{array}{l}\text { Wearing glove is not always } \\
\text { necessary }\end{array}$ & Know & 144 & 74.2 \\
\hline & $\begin{array}{c}\text { Safe system for hospital waste } \\
\text { management }\end{array}$ & Know & 190 & 97.9 \\
\hline \multirow{3}{*}{ 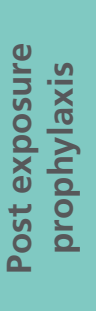 } & $\begin{array}{l}\text { Take post exposure prophylaxis } \\
\text { regime }\end{array}$ & Know & 93 & 47.9 \\
\hline & Clean the wound with water & Know & 190 & 97.9 \\
\hline & $\begin{array}{c}\text { Apply pressure on the wound to } \\
\text { arrest the bleeding }\end{array}$ & Know & 112 & 57.7 \\
\hline
\end{tabular}

documented that all the staff nurses had reported the injury. The reasons for underreporting is of interest. We found that the main reason for underreporting NSSIs was due to perceived low risk of the patient's status for viral infection transmission. This is probably related to self evaluation of the risk based on the patient's social and medical history. This is of concern as there are studies highlighting that self-evaluation of transmission risk following needle stick injuries most likely underestimates the real risk. This has implications for effective delivery of post exposure prophylaxis ${ }^{[22,23,24]}$.
The second most frequent reason for not reporting lack of perceived importance to report. This can be related to the notion that the injury sustained is 'probably'low-risk. if an injury is 'perceived as high risk, the person is more likely to report the incident. This merits exploration with regards to knowmledeg of medical studnets and doctors on seroconversion rates following exposure to blood infected with hepatitis B,C and HIV. One factor that appears reassuring in our study is that all respondents demonstatred awareness of the hospital reporting procedures. 
Table 11: Perception of risk of needle stick injuries of the respondents

\begin{tabular}{|c|c|c|c|c|c|c|}
\hline \multirow{2}{*}{ Statement } & \multicolumn{2}{|c|}{ SA/A } & \multicolumn{2}{|c|}{ Uncertain } & \multicolumn{2}{|c|}{ SDA/DA } \\
\hline & Frequency & $\%(\%)$ & Frequency & $\%(\%)$ & Frequency & $\%(\%)$ \\
\hline $\begin{array}{c}\text { All health care workers are at risk } \\
\text { of needlw stick injury }\end{array}$ & 166 & 85.6 & 5 & 2.6 & 23 & 11.9 \\
\hline $\begin{array}{l}\text { Needle stick injury cannot be } \\
\text { avoided at work place }\end{array}$ & 52 & 26.8 & 18 & 9.3 & 124 & 63.9 \\
\hline $\begin{array}{c}\text { Fatiguability and excessive } \\
\text { workload can result in needle } \\
\text { stick injuries. }\end{array}$ & 100 & 51.5 & 23 & 11.9 & 71 & 36.6 \\
\hline $\begin{array}{l}\text { Needle stick injuries can result in } \\
\text { life threatening infections }\end{array}$ & 14 & 7.3 & 18 & 9.3 & 161 & 83.4 \\
\hline $\begin{array}{l}\text { Unavailability of protective } \\
\text { equipment makes one prone to } \\
\text { get needle stick injuries }\end{array}$ & 95 & 49.2 & 25 & 13.0 & 73 & 37.8 \\
\hline $\begin{array}{c}\text { Posting at Obstetrics and } \\
\text { Gynaecology ward increses the } \\
\text { health care worker at risk of } \\
\text { needle stick injury. }\end{array}$ & 28 & 14.5 & 46 & 23.8 & 119 & 61.7 \\
\hline $\begin{array}{l}\text { Reporting after needle stick } \\
\text { injury is not much useful }\end{array}$ & 15 & 7.9 & 13 & 6.8 & 162 & 85.3 \\
\hline
\end{tabular}

\section{Study Limitation}

The limitation of our study is is that it is restricted to only one speciality.. To fully understand the exact magnitude of the problem, a multispecialty and multisite analysis is required. It is also important to note that a large pool of our study consist of medical student and thus ambiguity of data might appear in comparison to other studies.

\section{Conclusion and Recommendation}

There is a fair understanding of Universal Work Precaution among the HWCs in the Obstetrics and Gynaecology Department in tertiary hospitals. However, there still exist a large gap between their knowledge, attitude and practice of the universal work precaution. As noted in the study, the highest 
prevalence of needle stick injury and its' underreporting is among medical students. Therefore, exposure prevention among the students must be an institutional concern, and strengthening of universal work precautions in clinical skills at early phase of medical curriculum is mandatory. Completion of three doses of Hepatitis B must be reiterated and HWCs must also be aware of their antibody status.

\section{Acknowledgement}

Acknowledgement goes to the Director of Hospital, Hospital Tuanku Ja'afar, Seremban and Hospital Port Dickson, Dr Krishna Kumar, Consultant and Head of Department of Obstetrics and Gynaecology,Hospital Tuanku Ja'afar,Jalan Rasah 70300 Seremban,Negeri Sembilan,Malaysia, Dr Sivanewaran a/l Jeyarasalinggam Specialist Obstetrician and Gynaecologist, Hospital Port Dickson, Jalan Pantai, 71050 Port Dickson, Negeri Sembilan.

\section{Conflict of Interest}

The authors declare that there are no conflicts of interest involved in the preparation of this manuscript.

\section{References}

1. Who.int. WHO | Needlestick injuries [Internet]. 2015 [cited 13 January 2015]. Available from: http://www.who.int/ occupational_health/topics/needinjuries/en/

2. Pruss-Ustun A, Rapiti E, Hutin Y. Sharp's injuries: Global burden of disease from sharps injuries to health-care workers. Geneva; World Health Organization; 2003.

3. Bhardwaj A, Sivapathasundaram N, Yusof MF, Minghat AH, Swe KMM and Sinha NK. The Prevalence of Accidental Needle Stick Injury and their Reporting among Healthcare Workers in Orthopaedic Wards in General Hospital Melaka, Malaysia. Malaysian Orthopaedic Journal. 2014;Jul 2014(8(2):6-13.
4. National Institute of Occupational Safety and Health. Preventing needlestick injuries in health care settings. Ohio, Cincinnati : National Institute for Occupational Safety and Health. (DHHS (NIOSH) Publication No. 1999; 2000-108).

5. Ministry of Health Malaysia. Incidence Rate of Needlestick Injuries Among Health Care Workers within the Ministry of Health: Quality Assurance Indicator, 1998.

6. Ministry of Health Malaysia. AIDS series, Universal Infection Control Precautions, 1997.

7. Department of Occupational Safety and Health Malaysia. Code of Practice on Prevention and Management of HIV/ AIDS at the Workplace, 2001.

8. Norsayani MY, Noor HI. Study on incidence of needle stick injury and factors associated with this problem among medical students. Journal of Occupational Health. 2003; 45:172-8.

9. http://www.ncbi.nlm.nih.gov/pubmed/?term=Wilburn\%20 SQ\%5BAuthor\%5D\&cauthor=true\&cauthor_uid=15482091 Wilburn SQ. Needlestick and sharps injury prevention. http:// www.ncbi.nlm.nih.gov/pubmed/15482091 o Online journal of issues in nursing. Online J Issues Nurs. 2004 Sep 30;9(3):5.

10. Rampal L, Rosidah Z, Leong WS, et al. "Needle Stick and Sharps Injuries and Factors Associated Among Health Care Workers in a Malaysian Hospital". European Journal of Social Sciences.2010;13(3):354-362

11. Ljiljana Markovic Denic, Irena Ostric, Andrija Pavlovic, Dimitra Kalimanovska Ostric. http://www.openaccessarticles.com/ read/605931-0_Knowledge_and_occupational_exposure_to_ blood_and_body_fluids_among_health_care_workers_and_ medical_students o Knowledge and occupational exposure to blood and body fluids among health care workers and medical students http://www.openaccessarticles.com/journal/0354950X_Acta_chirurgica_iugoslavica+Acta_chir_iugo o Acta chirurgica iugoslavica: Acta chir iugo. 2012; 59(1)

12. Lin Yang and Barbara Mullan, "Reducing Needle Stick Injuries in Healthcare Occupations: An Integrative Review of the Literature ISRN Nursing Volume 2011 Article ID 315432, 11 pages

13. Voide C, Darling KE, Kenfak-Foguena A, Erard V, Cavassini M, Lazor-Blanchet $C$. Underreporting of needlestick and sharps injuries among healthcare workers in a Swiss University Hospital. Swiss Med Wkly. 2012;142:w13523

14. http://www.researchgate.net/researcher/2045413237_ Fernanda_Ribeiro_Fagundes_de_Souza-Borges Fernanda Ribeiro Fagundes de Souza-Borges, Larissa Araújo Ribeiro, http://www.researchgate.net/researcher/9487819_Luiz_ Carlos_Marques_de_Oliveira Luiz Carlos Marques de Oliveira. Occupational Exposures to Body Fluids and Behaviors Regarding Their Prevention and Post-Exposure among Medical and Nursing Students at A Brazilian Public University. Rev Inst Med Trop Sao Paulo. 2014 Mar-Apr; 56(2): 157-163.

15. Arman Azadi, Monireh Anoosheh, Ali Delpisheh. Frequency and barrier of under reported needlesticko injuries amongst Iranian 


\section{INTERNATIONAL ARCHIVES OF MEDICINE \\ Section: International Online Medical Conference

\section{Presented at $1^{\text {st }}$ International Online BioMedical Conference}

Vol. 8 No. 181 doi: $10.3823 / 1780$ nurses, a questionnaire survey. Journal of Clinical Nursing 2010; 20: 488-493.

16. Mehrdad Askarian, Leila Malekmakan. The Prevalence of Needle Stick Injuries in Medical, Dental, Nursing and Midwifery Students at the University Teaching Hospitals of Shiraz, Iran. Indian Journal of Medical Sciences 2006; 60 (6)(): 227-32.

17. Isurujith K Liyanage, Tskrd Caldera, Rajapaksha Rwma, Ck Liyange, Pubudu De Silva, Im Karunathilake. Sharps Injuries among Medical Students In The Faculty of Medicine, Colombo, Sri Lanka. International Journal of Occupational Medicine and Environmental Health 2012; 25 (3): 275-80.

18. Smith DR, Mihashi $M$, Adachi $Y$, Nakashima $Y$ \& Ishitake $T$. Epidemiology of Needle stick And Sharps Injuries Among Nurses In A Japanese Teaching Hospital. Journal of Hospital Infection 2006; 64(): 44-49

19. S. Pattnaik, D. Pattnaik, N. Rout. Prevalence of Needle Stick Injuries and Factors Associated with it among Nurses of a Tertiary Care Hospital in Bhubaneswar, East India. International Journal of Nursing Education 2012; 4(2)(): 51-54.

20. Ozer ZC, Bektas HA. Needles stick injuries during education period in nursing students in Turkey. Procedia Soc. Behav Sci. 2012;46:3798-801.

21. Saleem $T$, Khalid U, Ishaque S, Zafar A. Knowledge.

\section{Comment on this article:}

\section{(f) $[$ in $8+\mathbf{S} P$}

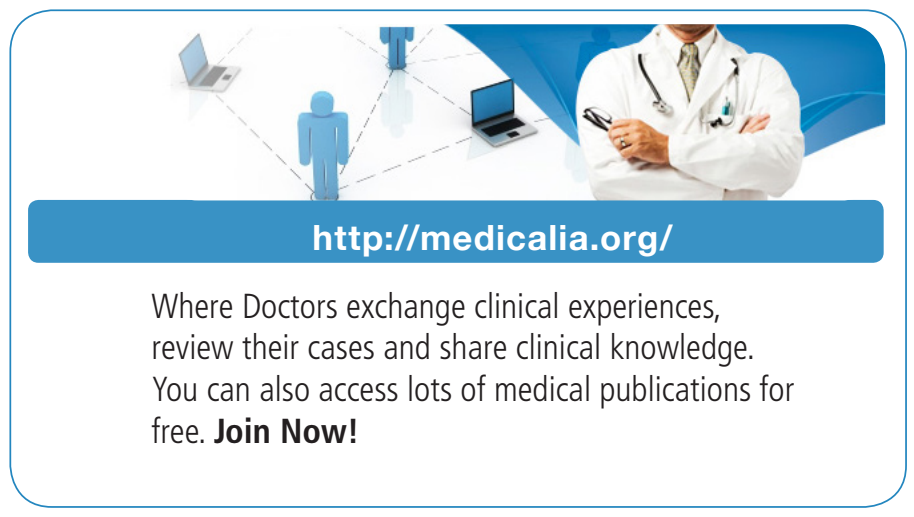

\section{Publish with iMedPub}

\section{http://www.imed.pub}

International Archives of Medicine is an open access journal publishing articles encompassing all aspects of medical science and clinical practice. IAM is considered a megajournal with independent sections on all areas of medicine. IAM is a really international journal with authors and board members from all around the world. The journal is widely indexed and classified Q1 in category Medicine. 